\title{
Soil biostabilisation and interaction with compaction processes for earthen engineering structures production
}

\author{
๑E. Bernat-Maso $₫$, $₫$ L. Gil ${ }^{\mathrm{a}}, \oplus$ M.J. Lis ${ }^{\mathrm{b}}, \oplus \mathrm{E}$. Teneva $^{\mathrm{a}}$ \\ a. Strength of Materials and Structural Engineering Department, Universitat Politècnica de Catalunya, (Terrassa, Spain) \\ b. Department of Chemical Engineering, Universitat Politècnica de Catalunya, (Terrassa, Spain) \\ ernest.bernat@upc.edu
}

\begin{abstract}
Interaction between microbially induced calcium carbonate precipitation (MICP) and compaction procedures to stabilise raw soil materials has been studied with the aim of producing earthen engineering structures. Initial tests to optimise MICP in aqueous medium and in selected soils were performed. MICP and compaction were finally applied to assess mediumsize elements. The main result was that sandy soils should be compacted before irrigation treatment to close the existing voids and prevent bacterial sweeping, whereas clayey soils should be compacted after irrigation treatment to avoid the plugging effect. MICP improved small sand soil compressive strength by up to $32 \%$ over the value reached by compaction alone. However, MICP had no positive effect on coarse soils and soils with an optimum particle size distribution: MICP treatment was not able to fill large connected voids in the first case and it caused little void generation due to bacteria sporulation in the second.
\end{abstract}

KEYWORDS: Particle size distribution; Mineralizer; Kinetic; Compressive strength.

Citation/Citar como: Bernat-Maso, E.; Gil, L.; Lis, M.J.; Teneva, E. (2021) Soil biostabilisation and interaction with compaction processes for earthen engineering structures production. Mater. Construcc. 72 [343], e256. https://doi.org/10.3989/mc.2021.00221.

RESUMEN: Bioestabilización de suelos e interacción con los procesos de compactación para la producción de estructuras ingenieriles de tierra. Se estudió la interacción entre la precipitación de carbonato de calcio inducida por bacterias (MICP) y los procesos de compactación para estabilizar suelos naturales para producir estructuras de tierra. Se realizaron ensayos iniciales en medio acuoso para optimizar la MICP. El uso conjunto de MICP y compactación fue evaluado en elementos de tamaño medio. Los resultados indican que los suelos arenosos deben ser compactados antes de los tratamientos por irrigación para cerrar los huecos evitando el lavado de bacterias, mientras que los suelos arcillosos deben ser compactados después de las irrigaciones para evitar colmatar la superficie. La MICP mejoró la resistencia a compresión de la arena fina en un 32\% en comparación con únicamente compactar. No obstante, no mejoró la resistencia de suelos granulares ni con una distribución de partículas óptima, por la interconexión de poros en el primer caso y la generación de vacíos por esporulación en el segundo.

PALABRAS CLAVE: Distribución del tamaño de partícula; Mineralizador; Cinética; Resistencia a compresión.

Copyright: C2021 CSIC. This is an open-access article distributed under the terms of the Creative Commons Attribution 4.0 International (CC BY 4.0) License. 


\section{INTRODUCTION}

Earthen materials have been used in construction for thousands of years because they are available at a low cost, among other advantages (1). More than one-third of the world population lived in earthen buildings at the beginning of this century (2). Competent soil layers are the basis for almost all terrestrial transportation infrastructures in civil engineering. Hence, earth can be considered one of the most important construction materials nowadays. To this end, soils are commonly consolidated by compaction and the addition of stabilisers to enhance their mechanical properties. Portland cement is the most common stabiliser. However, its production is associated with large $\mathrm{CO}_{2}$ emissions (3). To overcome this drawback and develop a more sustainable construction material, microbially induced calcium carbonate precipitation (MICP) has been explored as an alternative. Nevertheless, considering the interaction between compaction and MICP is a pending issue in the literature that must be addressed as part of the path for developing this novel and sustainable construction material, whose application may be extended to architectural purposes if the mechanical requirements were reached.

Several authors have reported the environmental sustainability of MICP (4-6); however, it remains a controversial topic. Mujah et al. (7) indicated that ammonia production (as a hydrolysis by-product of MICP) and energy consumption for the production of purified calcium chloride (required for MICP) are still unresolved issues. Thus, the sustainability of MICP is uncertain.

Economically, MICP is more expensive than cement stabilisation, according to Ivanov and Chu (8). However, other authors have reported the possibility of reusing the enzymatic capacity of bacteria for 2-3 treatments to reduce the long-term costs (9). In this line, it is also possible to think in limiting the negative impact of the conservation interventions on soil substructures, like reducing out-of-service time or reducing residues generation. The possibility of easily performing non-invasive maintenance operations, by benefitting from reusing enzymatic capacity of bacteria, may be one advantage of MICP over other stabilisation alternatives.

The time savings of MICP soil stabilisation have been highlighted by some researchers as an additional benefit $(10,11)$, indicating that cementation may occur in less than $24 \mathrm{~h}$ (12).

The lower viscosity of microbial suspensions may be an advantage over Portland cement injections, especially for soils with low porosity. Ginn et al. (13) proved that the bacterial concentration was reduced along the injection path. Cheng et al. (14) demonstrated the possibility of pore plugging near the injection point. Both effects may limit the penetration of MICP treatments into soils.
Although these drawbacks remain, microbial biotechnology is a promising research direction for civil engineering applications (15). The first use of soil bacterial treatments was in the 1980 s, exploiting the plugging effect for sealing oil reservoirs (16-18). Currently, the main research direction of microbial biotechnology in the construction industry is in the development of self-healing concrete (19-25). The results are controversial, and no practical applications of this technology have been published.

Research on the applicability of microbial biotechnology in the construction industry is mostly based on MICP; the fundamentals were detailed in the first book on the topic by Ivanov and Stabnikov (26). Researchers have analysed the mechanical $(27,28)$ and physical (29) properties of both soils (30) and cementitious materials (31) stabilised with MICP.

Focusing on the analysis of the calcium carbonate precipitation process, the influence of different factors, including the $\mathrm{pH}$ value, the concentration of bacterial cells, the concentration of calcium ions, the temperature, the possibility of encapsulating cells, and the rhythm for adding these compounds to the soil have been studied in detail $(15,21,32-34)$. According to these references, the most commonly used bacteria for MICP is Sporosarcina pasteurii, due to its strong ability to hydrolyse urea, which accelerates calcium carbonate precipitation.

Most research on MICP applications for soil stabilisation has been conducted in laboratory conditions on standardised soils. Only a few studies have focused on actual-scale tests (32) or used actual soils. Little research has combined compaction and bioconsolidation processes (35), although it is a necessary step in extending MICP to terrestrial transportation infrastructure applications.

According with presented references, MICP stabilisation of soils has been addressed from biological, chemical, physical and geomechanics point of view. Nevertheless, considering combined MICP-compacted soil as a general construction material and assessing its mechanical performance in terms of strength and deformability is far less studied.

The main purpose of this research was to assess the feasibility of using MICP for stabilising realistic soils subjected to compaction. The effects on the compressive strength and stiffness were studied. To achieve this objective, a four-step experimental campaign was defined: (i) optimizing the MICP process in an aqueous medium; (ii) implementing and optimizing the MICP process in four different realistic soils; (iii) studying the interaction between MICP and compaction; (iv) assessing the feasibility of combining MICP and compaction processes for stabilising realistic soil samples. To the best of the authors' knowledge, this research compares, for the first time, the compaction of soils before and after MICP biostabilisation, which is a required step forward for civil engineering applications. 


\section{MATERIALS AND METHODS}

\subsection{Materials}

\subsubsection{Bacterial suspension and Bang medium broth}

Bacterial suspension production was previously described in (35). Sporosarcina pasteurii were grown in an aerated aseptic medium at a stable temperature $\left(30^{\circ} \mathrm{C}\right)$ and $\mathrm{pH}>8$. Foam formation was not prevented. The resulting product was a suspension of Sporosarcina pasteurii in Bang medium with a concentration of 7E8-9E8 $\mathrm{cfu} / \mathrm{ml}$. The Bang medium was produced according to the instructions in (33).

\subsubsection{Treatment solutions}

The first treatment solution dissolved urea and calcium (from calcium chloride dihydrate or calcium lactate) into distilled water; the second treatment used Bang medium (33). The first treatment solution was used for kinetics tests (section 2.2.1) and to assess the possibility of saving Bang medium costs (section 2.2.3). The additional urea concentration in the treatment solutions was $20 \mathrm{~g} / 1(333 \mathrm{mmol} / \mathrm{l})$, the calcium chloride dihydrate concentration was $3.675 \mathrm{~g} / 1\left(25 \mathrm{mmol} / 1\right.$ of $\left.\mathrm{Ca}^{2+}\right)$ or $36.75 \mathrm{~g} / 1$ (250 mmol/1 of $\mathrm{Ca}^{2+}$ ) depending on the experiment, and the calcium lactate concentration was $5.45 \mathrm{~g} / 1(25 \mathrm{mmol} / \mathrm{l}$ of $\mathrm{Ca}^{2+}$ ). Temperature, $\mathrm{pH}$, and aeration were not controlled during the soil treatment processes. Kinetic tests were performed under aerated and constant temperature conditions, and the $\mathrm{pH}$ evolution was controlled.

\subsubsection{Soils}

Four commercial soils were studied; their particle size distributions are presented in Figure 1. Small particle sand (SS), coarse sand (CS), clayey sand (M1), and sandy clay (M2) were considered to cover a wide range of realistic soils for stabilisation. In Figure 1, it is observed that approximately $50 \%$ of the mass of CS was attributed to particles greater than $1 \mathrm{~mm}$ in size. Approximately $50 \%$ of the mass of SS and M1 was attributed to particles greater than $0.2 \mathrm{~mm}$ in size. Approximately $50 \%$ of the mass of M2 was attributed to particles greater than $0.074 \mathrm{~mm}$ in size, indicating 50\% silt-clay content. All soils were supplied by a local producer, Sorres i graves Egara S.A. Soil was not aseptic, and no treatment was applied before stabilisation.

\subsection{Testing methods and specimens}

Different specimen definitions and testing methodologies were used for the four distinct studies

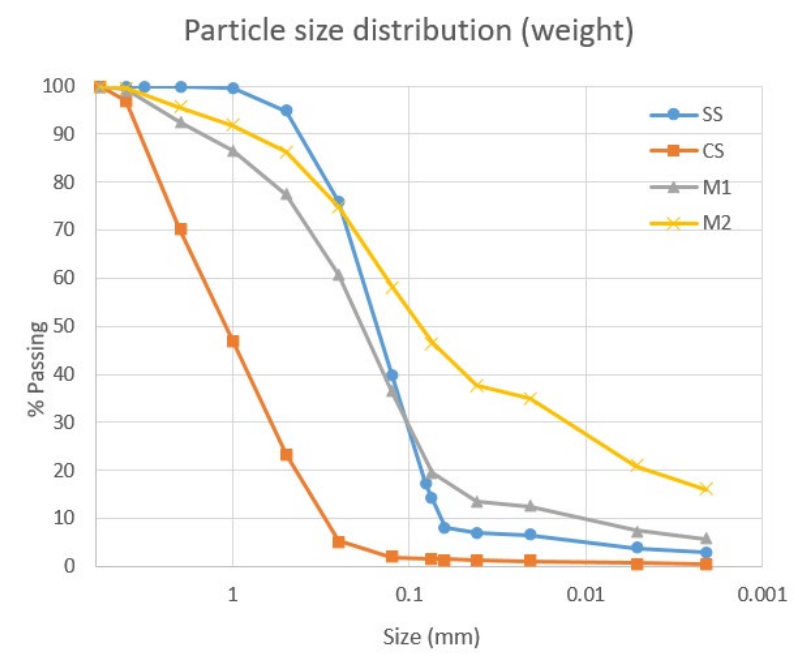

FIgURE 1. Particle size distribution of the used soils. SS Small particle sand. CS Coarse particle sand. M1 clayley sand. M2 Sandy clay.

conducted in this research. Details for each campaign are provided in the following paragraphs.

\subsubsection{Study of precipitation kinetics}

The aim of this study was to set the optimum conditions for calcium carbonate precipitation in a liquid environment promoted by Sporosarcina pasteurii MICP. The influences of the culture temperature, the calcium source, the calcium concentration, the bacterial concentration, and the combined effect of increasing bacterial and calcium concentrations were studied through six experiments.

For each experiment, 11 Erlenmeyer flasks with the same bacterial suspension volume were introduced into a water bath prepared with a shaking system (see Figure 2); the temperature was maintained constant. The corresponding calcium and urea solutions were added to all flasks to reach the compound concentrations listed in Table 1. The water bath maintained the desired temperature and the flasks were continuously shaken. The first flask was removed immediately after the addition of calcium and urea. The quantity of precipitated calcium carbonate was determined by filtering the liquid through a previously weighed filtering paper, drying it for $24 \mathrm{~h}$, and weighing it again. One flask was removed every hour for the following $10 \mathrm{~h}$ for calcium carbonate quantification. In addition, the theoretically consumed urea was calculated by stoichiometry from the measured calcium carbonate precipitation. The precipitated particles were observed under a microscope to determine their morphology.

\subsubsection{Study of treatment procedure for non-com- pacted soils}

The kinetics of calcium carbonate precipitation can be altered by a non-aseptic solid soil environment. 

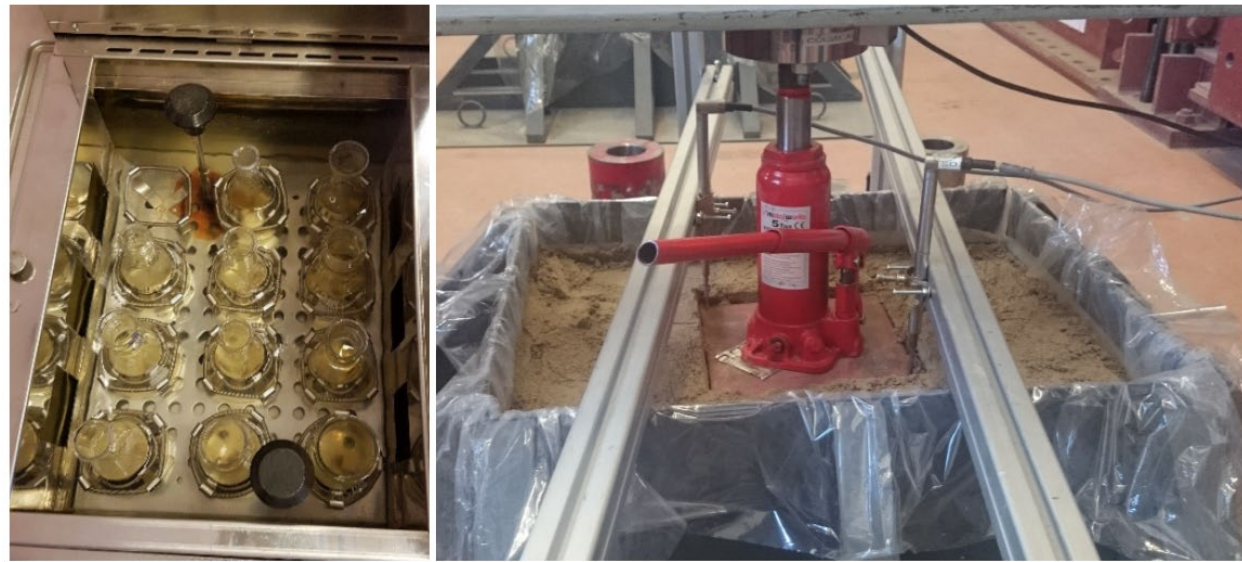

FIGURE 2. Water bath with shaking system for the study of precipitation kinetics (left) and testing configuration for the comparative load-bearing experiments (right).

TABLE 1. Sporosarcina pasteurii MICP kinetic experiments.

\begin{tabular}{cccccc}
\hline $\begin{array}{c}\text { Experi- } \\
\text { ment }\end{array}$ & $\begin{array}{c}\text { Tem- } \\
\text { perature } \\
\left({ }^{\circ} \mathrm{C}\right)\end{array}$ & $\begin{array}{c}{[\text { racte- }} \\
(\mathrm{cfu} / \mathrm{ml})\end{array}$ & $\begin{array}{c}{\left[\mathrm{CH}_{4} \mathrm{~N}_{2} \mathrm{O}\right]} \\
(\mathrm{mmol} / \mathrm{l})\end{array}$ & $\begin{array}{c}\text { Calcium } \\
\text { source }\end{array}$ & $\begin{array}{c}{\left[\mathrm{Ca}^{2+}\right]} \\
(\mathrm{mmol} / \mathrm{l})\end{array}$ \\
\hline $\mathrm{K} 1$ & 37 & $5.1 \mathrm{e} 6$ & 333 & $\mathrm{CaCl}_{2} \cdot 2 \mathrm{H}_{2} \mathrm{O}$ & 25 \\
\hline $\mathrm{K} 2$ & 25 & $5.1 \mathrm{e} 6$ & 333 & $\mathrm{C}_{6} \mathrm{H}_{10} \mathrm{CaO}_{6}$ & 25 \\
\hline $\mathrm{K} 3$ & 25 & $5.1 \mathrm{e} 6$ & 333 & $\mathrm{CaCl}_{2} \cdot 2 \mathrm{H}_{2} \mathrm{O}$ & 25 \\
\hline $\mathrm{K} 4$ & 25 & $5.1 \mathrm{e} 6$ & 333 & $\mathrm{CaCl}_{2} \cdot 2 \mathrm{H}_{2} \mathrm{O}$ & 250 \\
\hline $\mathrm{K} 5$ & 25 & $5.1 \mathrm{e} 8$ & 333 & $\mathrm{CaCl}_{2} \cdot 2 \mathrm{H}_{2} \mathrm{O}$ & 25 \\
\hline $\mathrm{K} 6$ & 25 & $5.1 \mathrm{e} 8$ & 333 & $\mathrm{CaCl}_{2} \cdot 2 \mathrm{H}_{2} \mathrm{O}$ & 250 \\
\hline
\end{tabular}

Eighty experiments were performed to determine the treatment procedure resulting in the highest compressive strength for each soil, without compaction.

These experiments studied the influences of the bacterial presence, the bacterial concentration, performing a single treatment or periodic treatments, the time between periodic additions of urea and calcium, and including a second bacterial inoculation.

The testing procedure (see Figure 3 ) began by placing the dry soil into a $45 \mathrm{~mm}$ internal diameter transparent PVC pipe with a $75 \mu \mathrm{m}$ sieve sheet covering the bottom end to allow excessive fluid to be drained. The pipes were filled with soil $(100 \mathrm{~mm}$ in height) and $55 \mathrm{ml}$ of Bang medium with suspended Sporosarcina pasteurii (T3-T10 in Table 2) or $55 \mathrm{ml}$ of distilled water (T1 and T2 in Table 2) was added to $\mathrm{SS}, \mathrm{M} 1$, and M2 soil specimens. A volume of $45 \mathrm{ml}$ was used for CS specimens. These quantities $(55 \mathrm{ml}$ or $45 \mathrm{ml})$ were experimentally determined to ensure complete soil wetting without liquid flowing out of the sample. The liquid was added to the top of the specimens. Bang medium $(4 \mathrm{ml})$ was added $4 \mathrm{~h}$ after the first bacterial inoculation with Sporosarcina pasteurii (T3-T10 in Table 2). Treatments were started $24 \mathrm{~h}$ after the first liquid addition; $1.4 \mathrm{ml}$ of Bang medium was added with urea $(20 \mathrm{~g} / \mathrm{l})$ and calcium $(36.75 \mathrm{~g} / \mathrm{l})$ every $2 \mathrm{~h}$, five times per day for $5 \mathrm{~d}$, or every $4 \mathrm{~h}$, three times per day for $5 \mathrm{~d}$. The calcium ion source was calcium chloride dihydrate for all 80 experiments. The environmental temperature was $25^{\circ} \mathrm{C}$ for all tests.

Some experiments (T3 and T6 in Table 2) were performed with a single treatment addition $24 \mathrm{~h}$ after the first liquid addition. One experiment (T10) included a second bacterial inoculation $24 \mathrm{~h}$ after the first inoculation; treatment started $24 \mathrm{~h}$ later in this case.

The experimental list and the corresponding specifications are presented in Table 2. Each test was repeated twice for each type of soil.

Soil samples were unmoulded two days after finishing treatment and dried in indoor environmental conditions for three weeks before performing compressive tests. The top surfaces of the samples were polished using abrasive paper to obtain a plain surface parallel to the bottom surface to ensure convenient contact with the testing machinery. Specimens were measured (height and diameter) and tested with an unconfined uniaxial compression configuration at a loading rate of $1 \mathrm{~mm} / \mathrm{min}$. The load cell measured the applied load at $50 \mathrm{~Hz}$. The compressive strength value was corrected by a geometric factor according to (34). The average value was calculated.

\subsubsection{Influence of soil compaction time}

Assessing the interaction between compaction processes and biological precipitation of calcium carbonate was necessary to combine them in soil stabilisation activities. The best compaction time (before or after biological treatment) was studied. It was also intended to reduce the economic cost by replacing the Bang medium with distilled water for the periodic treatments. Compaction time and Bang replacement were both addressed in this experimental campaign.

The testing procedure was similar to the previous experiment (subsection 2.2.2), but included the 

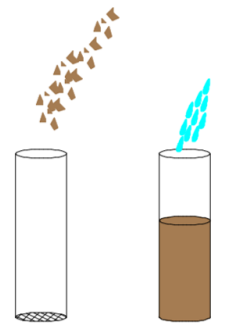

a

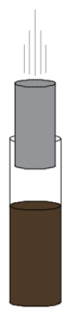

C

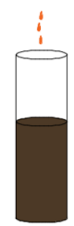

d

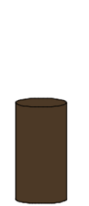

e

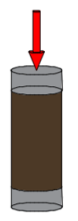

$f$
Figure 3. Procedure for the study of the treatment method and the influence of soil compaction time. (a) Filling the PVC pipe with soil. Sieve sheet in the bottom ending; (b) initial soil wetting; (c) compacting (only for corresponding cases; compaction was set after treatment in some cases); (d) treatment application; (e) unmolding and drying; (f) unconfined uniaxial compressive testing.

TABLE 2. Soil stabilisation experiments.

\begin{tabular}{cccc}
\hline Experiment & $\begin{array}{c}{[\text { Bacteria }]} \\
(\mathrm{cfu} / \mathrm{ml})\end{array}$ & $2^{\text {nd }}$ inoculation & $\begin{array}{c}\text { Treatment } \\
\text { period }(\mathrm{h})\end{array}$ \\
\hline T1 & - & $\mathrm{N}$ & - \\
\hline T2 & - & $\mathrm{N}$ & 2 \\
\hline T3 & $1 \mathrm{E} 7$ & $\mathrm{~N}$ & - \\
\hline T4 & $1 \mathrm{E} 7$ & $\mathrm{~N}$ & $\mathrm{~S}$ \\
\hline T5 & $1 \mathrm{E} 7$ & $\mathrm{~N}$ & 2 \\
\hline T6 & $1 \mathrm{E} 9$ & $\mathrm{~N}$ & - \\
\hline T7 & $1 \mathrm{E} 9$ & $\mathrm{~N}$ & $\mathrm{~S}$ \\
\hline T8 & $1 \mathrm{E} 9$ & $\mathrm{~N}$ & 2 \\
\hline T9 & $1 \mathrm{E} 9$ & $\mathrm{~N}$ & 4 \\
\hline T10 & $1 \mathrm{E} 9$ & $\mathrm{Y}$ & 2 \\
\hline
\end{tabular}

compaction process, which was applied before the periodic treatment (CBB and CDD specimens in Table 3) or after periodic treatment $(\mathrm{CAB}$ and $\mathrm{CAD}$ specimens in Table 3 ). The compaction energy corresponded to the Modified Proctor test (36). The optimum moisture content was previously obtained: $9.26 \%, 5.67 \%, 15.66 \%$, and $16.42 \%$ for SS, CS, M1, and M2 soils, respectively. Moisture was tuned by adjusting the quantity of the first liquid addition (bacterial suspension in Bang medium) for the samples compacted before treatment. Samples compacted after treatment were weight-controlled during the drying process until the theoretical optimum moisture content was reached, and then compacted. An additional specimen was produced to check the actual moisture content at compaction.

Urea and calcium chloride dihydrate solution treatment was prepared in Bang medium (CBB and $\mathrm{CAB}$ experiments in Table 3) and distilled water (CBD and CAD experiments in Table 3) with the same concentration as in the previous specimens (section 2.2.2). Non-treated control samples (CBN in Table 3) were also produced.
Table 3 summarises the combination of treatment medium (Bang medium or distilled water) and compaction time. Three samples for each soil type and combination were tested with a uniaxial unconfined compression configuration. One additional specimen was used to control the moisture content at compaction for specimens compacted after treatment $(\mathrm{CAB}$ and CAD in Table 3). A total of 68 specimens were produced and tested for this study.

TABLE 3. Compaction and bang medium influence experiments on soil samples.

\begin{tabular}{ccc}
\hline Experiment & Compaction moment & Treatment medium \\
\hline CBN & Before & No Treatment \\
\hline CBB & Before & Bang medium \\
\hline CBD & Before & Distilled water \\
\hline CAB & After & Bang medium \\
\hline CAD & After & Distilled water \\
\hline
\end{tabular}

Bacterial concentration and treatment rhythm (in the case of treated specimens) depended on the soil type according to the best results of the previous experiments on non-compacted specimens (see sections 2.2.2 and 3.2). These parameters are summarised in Table 4. The calcium concentration was $250 \mathrm{mmol} / \mathrm{l}$.

TABLE 4. Bacterial concentration and treatment period used for compaction influence experiments.

\begin{tabular}{ccc}
\hline Soil & [Bacteria] $(\mathrm{cfu} / \mathrm{ml})$ & Treatment period $(\mathrm{h})$ \\
\hline SS & $1 \mathrm{E} 9$ & 2 \\
\hline CS & $1 \mathrm{E} 9$ & 4 \\
\hline M1 & $1 \mathrm{E} 9$ & 4 \\
\hline M2 & $1 \mathrm{E} 9$ & 2 \\
\hline
\end{tabular}

\subsubsection{Comparative load bearing experiments}

Two comparative experiments were performed to assess the mechanical performance of Sporosarcina pasteurii-induced calcium carbonate precipitation. The first experiment compared the compressive response of a laterally restrained compacted medium-size $(30 \mathrm{~cm}$ height $\times 55 \mathrm{~cm}$ length $\times 43 \mathrm{~cm}$ width) SS soil block with an analogous sample that was bacterially stabilised. The same comparison was performed with M2 soil. According to the results of the previous experiments, the optimum stabilisation procedure was implemented for each soil.

Specimen preparation followed these steps: a) soil was mixed with supply water for the control specimen and with Sporosarcina pasteurii suspension in Bang medium for the stabilised specimen. A quantity of water or Sporosarcina pasteurii was added to reach the optimum compaction moisture content. For Sporosarcina pasteurii, the bacterial 
concentration was reduced by dilution from $1 \mathrm{~L}$ of $1 \mathrm{E} 9 \mathrm{cfu} / \mathrm{ml}$ to the required liquid quantity by adding Bang medium; b) soil was moulded and a sample was extracted to control real moisture content; c) for compaction before treatment (SS), the specimen was compacted according to the modified Proctor method; d) a second bacterial inoculation was undertaken $24 \mathrm{~h}$ after mixing; e) treatment was applied by adding urea (333 $\mathrm{mmol} / \mathrm{l})$ and calcium chloride dihydrate $(250 \mathrm{mmol} / \mathrm{l})$ dissolved into Bang media every $2 \mathrm{~h}$, five times per day for $5 \mathrm{~d}$; f) for compaction after treatment (M2), the specimen was weighed daily until the optimal moisture content was reached $(10 \mathrm{~d})$ before compaction and extraction of a soil sample to check the actual moisture; g) specimens were left to dry and the moisture content stabilisation was controlled using ultrasound techniques according to (37); h) when the moisture content was stable $(7 \mathrm{~d}$ for SS control specimen, $14 \mathrm{~d}$ for M2 control specimen, $10 \mathrm{~d}$ for biostabilised SS specimen, and $21 \mathrm{~d}$ for biostabilised M2 specimen), the mechanical experiment was conducted. A load was applied using a $200 \mathrm{~mm}$ square steel plate; the applied load and the descending displacement were continuously measured using a load cell and an LVDT, respectively. The loading procedure followed (38). The maximum loading capacity of the jack was $50 \mathrm{kN}$, which corresponded to a stress of 1.25 $\mathrm{MPa}$.

\section{RESULTS AND DISCUSSION}

\subsection{Kinetics experiments}

Charts summarising the evolution of the remaining urea and the precipitated calcium carbonate for the kinetics experiments (Table 1) are presented in Figure 4. The morphology of the particles from the kinetics tests is shown in Figure 5.

Regarding the testing temperature, it was observed that increasing the temperature from $25^{\circ} \mathrm{C}$ to $37^{\circ} \mathrm{C}$ (K1 experiment vs. K3 experiment in Figure 4) did not increase the amount of calcium carbonate produced, as reported by other researchers (39) In fact, urea consumption and calcium carbonate production rates (slope of curves in Figure 4) were higher at lower temperatures $\left(25^{\circ} \mathrm{C}, \mathrm{K} 3\right.$, control experiment, Figure 4). It was only during the last period (from $9 \mathrm{~h}$ on) that urea consumption and the calcium carbonate precipitation rate increased in the higher temperature environment. The observed particles were qualitatively larger at higher temperatures (comparing Figure 5(a) for higher temperature and 5(c) for control temperature), although more small calcium carbonate particles were expected. This contradiction may result from a large number of the smallest particles passing through the filtering paper for the K1 (higher temperature) test; the resulting sample for observation may have missed the smallest calcium carbonate particles. Thus, it cannot be concluded that calcium carbonate production is greater at $25^{\circ} \mathrm{C}$ than at $37^{\circ} \mathrm{C}$, because $37^{\circ} \mathrm{C}$ is the recommended culture temperature in the literature (39). The results seem to indicate that calcium carbonate particles produced at higher temperatures may be smaller. Further testing, including the repetition of kinetic tests reducing the potential loss of the smallest particles and acquiring $\mathrm{pH}$ data is a must for future developments to confirm this justification for the obtained evidences.

Regarding the influence of the calcium source (comparing K3 calcium chloride dihydrate and K2 calcium lactate experiments in Figure 4), it was observed that using calcium lactate was not as efficient as using calcium chloride dihydrate. Calcium chloride (K3) produced over three times greater weight of particles than calcium lactate (K2). In addition, particles produced with calcium lactate did not exhibit the typical calcium carbonate shape and these were significantly larger $(100 \mu \mathrm{m})$ than any other particle observed in the kinetics tests. It is concluded that the particles observed in K2 were not calcium carbonate. That may be explained by the lower solubility of calcium lactate $\left(50 \mathrm{~g} / 100 \mathrm{ml}\right.$ at $60^{\circ} \mathrm{C}$, see (40)) compared with calcium chloride (134.5 g/100 $\mathrm{ml}$ at $60^{\circ} \mathrm{C}$ ). The lower solubility of calcium lactate produced a smaller number of free calcium ions to combine with carbonates, resulting in lower calcium carbonate production when calcium lactate was used as the source of calcium ions. Hence, calcium chloride dihydrate was chosen for all tests after as the source of calcium ions.

Increasing (multiplying by 10) the calcium concentration (K3 vs. K4 in Figure 4) produced an initial reduction in the calcium carbonate precipitation rate; urea hydrolysis decreased accordingly. However, from $6 \mathrm{~h}$ after the test start and on the calcium carbonate production continuously increased up to more than four times the reference value (K3 experiment in Figure 4). The shapes of the particles obtained in experiment $\mathrm{K} 4$ were qualitatively more aggregated (Figure $5(\mathrm{~d})$ ) than the reference experiment (K3, Figure 5 (c)). This behaviour may be explained by the initial blocking effect of the precipitation of calcium carbonate due to the high calcium chloride concentration and the resulting reduced $\mathrm{pH}$. After $6 \mathrm{~h}$ of bacterial hydrolysis of urea, $\mathrm{pH}$ overpassed the recommended threshold value $(\mathrm{pH}>9)$ to promote and accelerate calcium carbonate precipitation (K4). The availability of carbonate and calcium ions resulted in a faster production, leading to a qualitatively more aggregated morphology of the calcium carbonate.

Increasing (by 100 times) the concentration of Sporosarcina pasteurii (comparing experiments K3 and $\mathrm{K} 5$ in Figure 4) produced a ten-fold increase in 
K1

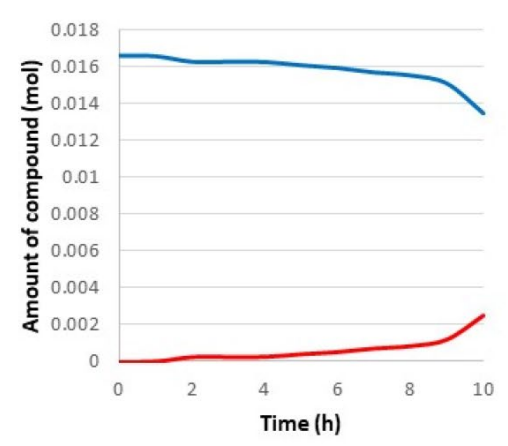

(a)

K3

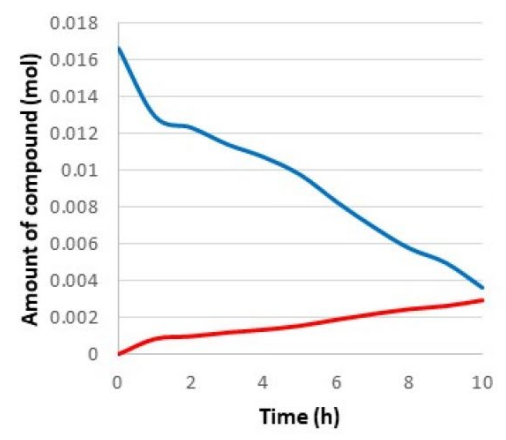

(c)

K5

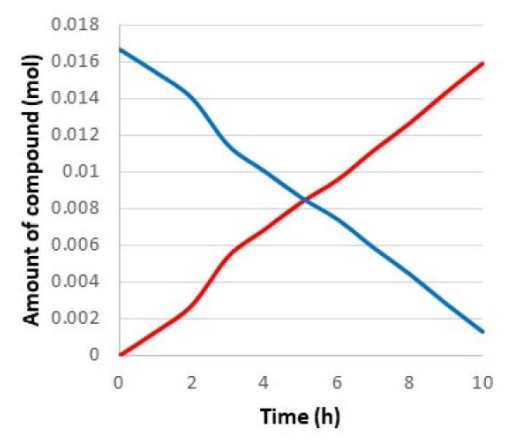

(e)
K2

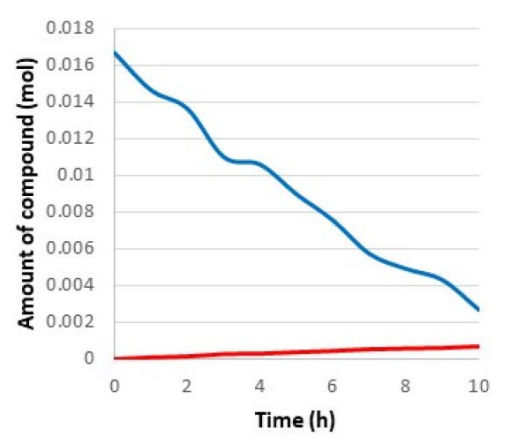

(b)

\section{K4}

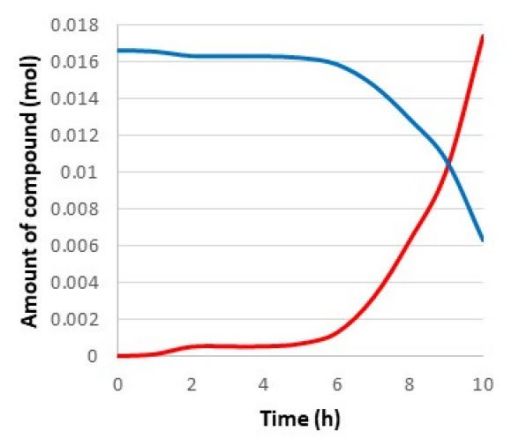

(d)

K6

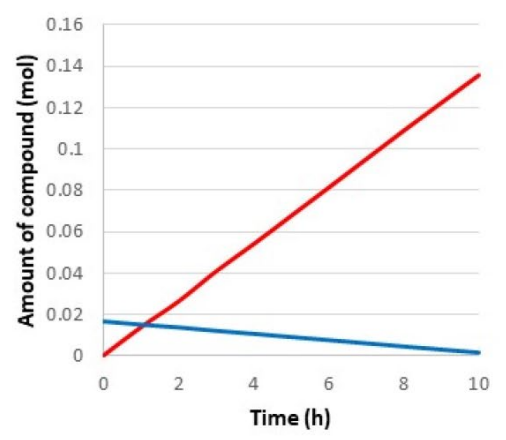

(f)

FIGURE 4. Evolution of the remaining urea (blue) and the produced calcium carbonate (red) for the kinetics experiments: (a) at $37^{\circ} \mathrm{C}$, (b) with calcium lactate, (c) control case at $25^{\circ} \mathrm{C}$ and using calcium chloride dihydrate, (d) higher concentration of calcium ions, (e) higher concentration of bacteria and (f) higher concentration of both bacteria and calcium ions.

calcium carbonate production; urea consumption was similar to that in the reference experiment (K3). An increase in the particle density and a decrease in the particle size are qualitatively observed by comparing Figure 5 (c) and Figure 5 (e). This response may be explained by the presence of more nucleation points (cells) with greater bacterial concentration (K5). Calcium carbonate precipitated around these nucleation points, generating more particles of smaller size than with lower bacterial concentration (K3).

The combination of increasing calcium (by ten times) and bacterial concentrations (by 100 times) (K6 vs. K3 in Figure 4) increased production of calcium carbonate (by 50 times). In addition, the production ratio was time-stable. The produced particles were small in size and highly aggregated, as shown in Figure 5 (f). This was the result of the combination of two independently observed effects: a large num- 


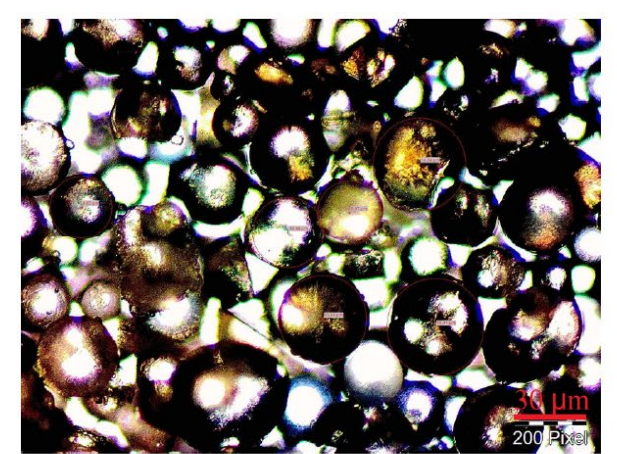

(a) K1

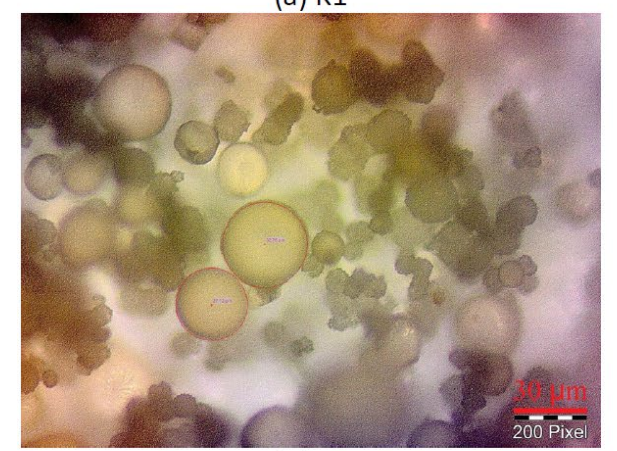

(c) $\mathrm{K} 3$

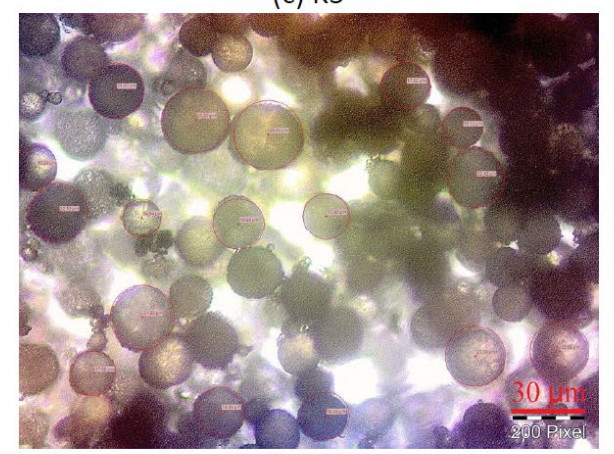

(e) $\mathrm{K5}$

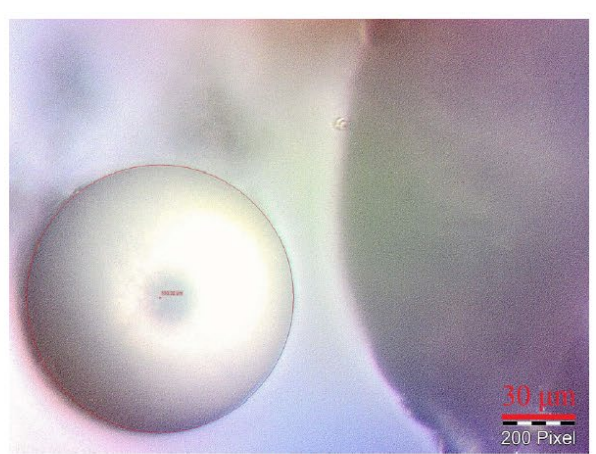

(b) K2

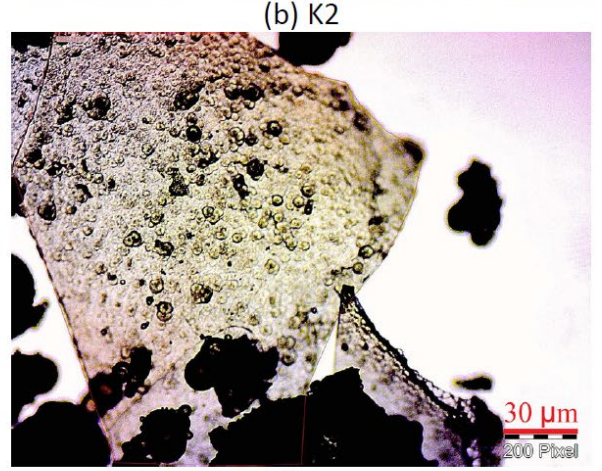

(d) K4

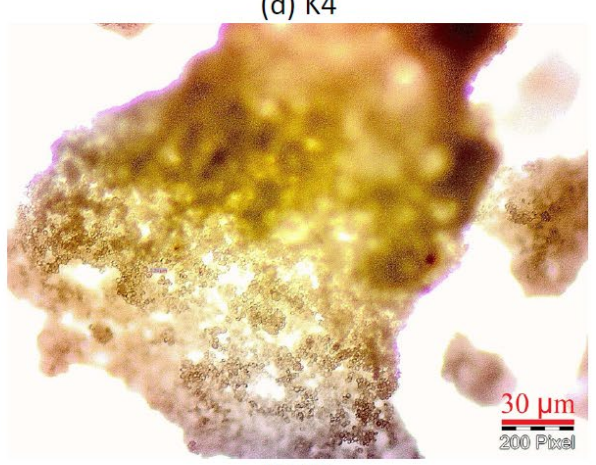

(f) $\mathrm{K} 6$

Figure 5. Particles observed in kinetics experiments: (a) at $37^{\circ} \mathrm{C}$, (b) with calcium lactate, (c) control case at $25^{\circ} \mathrm{C}$ and using calcium chloride dihydrate, (d) higher concentration of calcium ions, (e) higher concentration of bacteria and (f) higher concentration of both bacteria and calcium ions. 200 pix $=30 \mu \mathrm{m}$.

ber of nucleation points (high concentration of bacteria) producing a large number of particles, and the availability of free calcium ions (high calcium chloride concentration), causing aggregation of particles through faster production.

Summarizing the qualitative analysis of calcium carbonate precipitation kinetics from MICP, increasing the bacterial concentration increases the number of nucleation points; increasing the calcium concentration increases the aggregation of precipitated calcium carbonate.

\subsection{Treatment influence}

The average compressive strength of the two specimens tested in each experiment defined in Table 2 is summarised in Figure 6; the variation of each result is also included, with the range indicated by arrows. These results are compared pair by pair for each soil type to examine the influence of the different treatment alternatives.

Periodically adding urea and calcium dissolved in Bang medium to soils without adding Sporosarcina pasteurii (T1 vs. T2 in Figure 6) resulted in increased compressive strength for all soils, by a factor of up to five (SS soil; Figure 6(a)). Calcium carbonate may have precipitated from the direct reaction between urea and calcium chloride, even without the presence of Sporosarcina pasteurii. Hence, bacteria acted as a catalyser of calcium carbonate precipitation reaction.

Bacterial inoculation with no further treatment (T3 vs. T1 in Figure 6) increased the compressive strength of SS soil (up to 6 times) but decreased the compressive strength of CS and M1 soils, proving 
that the voids left by bacterial sporulation reduced the compressive strength in most of the cases. The results for M2 soils were analogous for the control (T1) and with bacteria only (T3) cases. For SS, with few original ordered voids, spores may contribute to filling the existing space more than generating new voids after bacteria sporulation, resulting in the reported strength increase. Nevertheless, further research including microscopic observation of the treated soils is necessary for confirmation of this justification.

Adding bacteria and performing periodic treatment (T2 (only treatment) vs. T5 (bacteria + treatment) in Figure 6) increased the compressive strength of clayey M1 and M2 soils, proving that bacterial activity was maintained under periodic irrigation conditions in clayey soils, whereas bacteria may have been partially removed from sandy soils (SS and CS) due to their interconnected porosity when irrigated with periodic treatments. This inferred statement is confirmed by analysing the cases with a single irrigation.

Performing a single irrigation process on soils that were previously inoculated with bacteria (T4 and $\mathrm{T} 7$ for low and high bacterial concentrations, respectively) reduced the compressive strength compared with only adding bacteria (T3 and T6 for low and high bacterial concentrations, respectively) for all soils (Figure 6). This effect was more evident in sandy soils (SS and CS) due to interconnected porosity. Thus, it is possible to conclude that bacterial removal by irrigation processes has been proven.

Repeating treatment irrigation (T5 and T8, irrigation every $2 \mathrm{~h}$ for low and high bacterial concentrations, respectively, vs. T4 and T7, corresponding single irrigation, in Figure 6) increased the compressive strength for all soils, proving that the remaining bacteria after the first irrigation removal required urea and calcium supply to produce calcium carbonate.

Spacing irrigation time up to $4 \mathrm{~h}$ (T9 (4 h) vs. T8 (2 h) in Figure 6) decreased the compressive strength of SS and M2 soils, but increased the compressive strength of CS and M1 soils approximately $25 \%$. A slower treatment rhythm was favourable for more porous soils (CS and M1) even with smaller amounts of treatment compounds (urea and calcium chloride). Preventing bacterial removal is the key issue in porous soils. In contrast, soils that retained bacteria (SS and M2) achieved greater compressive strength with increased irrigation repetitions, increasing urea and calcium chloride input and enhancing MICP. Hence, it is only recommendable to increase the treatment rhythm for those cases whose bacterial removal is little like clayey soils and small particle sandy soils.

Increasing (by 100 times) bacterial concentration (T3 vs. T6, T4 vs. T7, and T5 vs. T8 in Figure 6) increased the compressive strength for almost all soils and treatment rhythms, proving that Sporosarcina pasteurii was effective in promoting the MICP process. CS soil compressive strength was increased up to six times with increased bacterial concentration and no treatment (T3 vs. T6), suggesting that repeated irrigation was especially detrimental for coarse soil due to bacterial removal. Two exceptions were observed: M2 soil with single treatment showed no clear difference (T4 vs. T7), and M1 soil with $2 \mathrm{~h}$ periodic treatment exhibited a compressive strength reduction (of approximately $1 / 3$ ) with increased bacterial concentration (T5 vs. T8 in Figure 6). A hypothesis to explain this result is that increasing the volume of the MICP process with a greater bacterial concentration and extending it over time owing to the greater volume of urea and calcium ( $2 \mathrm{~h}$ irrigation treatment) may have promoted calcium carbonate formation even on dried M1 soil specimens. This late MICP process may have broken typical clay bonds, which were thought to be weaker in the M1 soil than in the M2 soil, which had a higher clay content. This hypothesis requires additional microscopic observation to be confirmed but it points out the idea that there is a counterproductive interaction between clay drying process and MICP that requires extensive research.

Adding a second bacterial inoculation (T10 vs. T8 in Figure 6) increased the compressive strength in all cases. The effect was more significant for SS and M1 soils, which doubled their respective compressive strengths. A second bacterial inoculation increased the bacteria amount and also allowed the first bacterial inoculation to rest an additional $24 \mathrm{~h}$ before starting irrigation treatments. The bacteria had more time to set, and less bacterial removal caused by irrigation was likely. From a practical point of view, it would be of major interest to research on the possibility of spacing the starting time of the treatment respect from the initial bacterial inoculation, especially for those soils which showed greater bacterial removal due to treatment liquid flux.

\subsection{Influence of compaction time}

The moisture content at compaction time of the samples compacted after treatment, the optimum moisture content, and the difference between these two values are presented in Table 5 to better understand the compressive strength results in Table 6 . The results of the study on the influence of applying compaction before or after periodic treatments and the study on the influence of replacing the Bang medium with distilled water are presented in terms of the average value of three tests of the compressive strength for each combination (Table 6) of the tests defined in Table 3 and Table 4.These results showed that sandy soils reached greater compressive strength $(13 \%$ and $87 \%$ for SS and CS, respectively) when compacted before urea and calcium chloride treatment irrigation. 


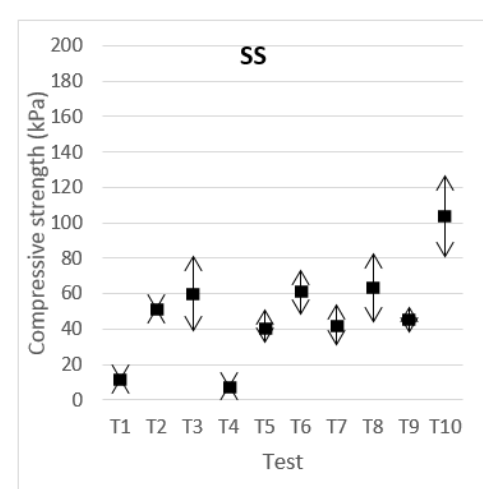

(a)

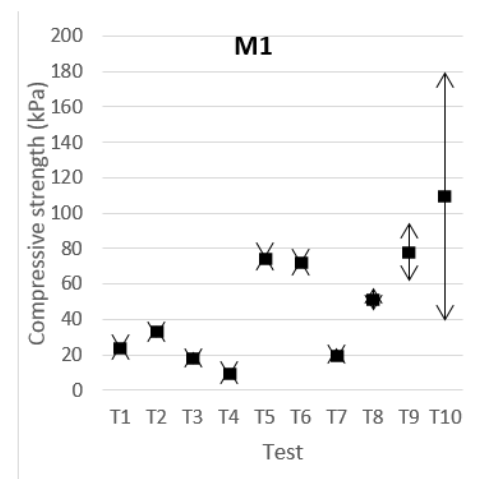

(c)

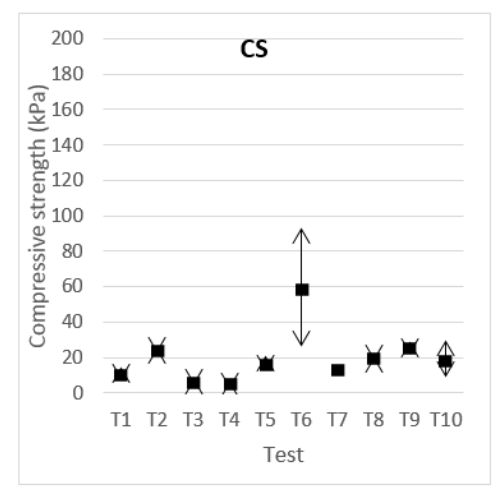

(b)

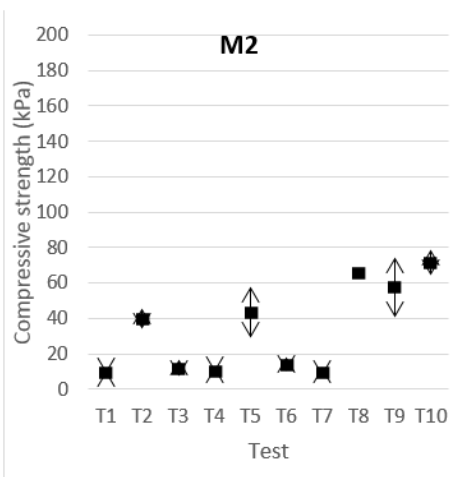

(d)

$\mathrm{T} 1$ vs. T2. Influence of only pouring treatment (T2) respect control case (T1)

$\mathrm{T} 1$ vs. T3. Influence of only bacterial inoculation (T3) respect control case (T1)

$\mathrm{T} 2$ vs. T5. Influence of including bacteria (T5) if there is treatment available (T2)

$\mathrm{T} 3$ vs. $\mathrm{T} 4$ and $\mathrm{T} 6 \mathrm{vs}$. $\mathrm{T} 7$. Influence of a single treatment irrigation $(\mathrm{T} 4, \mathrm{~T} 7)$ respect to no treatment irrigation (T3, T6). Low (T3, T4) and high (T6, T7) bacteria concentration.

$\mathrm{T} 4$ vs. $\mathrm{T} 5$ and $\mathrm{T} 7 \mathrm{vs.} \mathrm{T} 8$. Influence of repeating irrigation (T5, T8) respect a single irrigation (T4, $\mathrm{T} 7)$, for low (T4, T5) and high (T7, T8) bacteria concentration.

T8 vs. T9. Influence of irrigation frequency, $2 \mathrm{~h}(\mathrm{~T})$ and $4 \mathrm{~h}(\mathrm{~T})$

$\mathrm{T} 3, \mathrm{~T} 4$ and $\mathrm{T} 5$ vs. T6, T7 and $\mathrm{T} 8$ respectively. Influence of increasing (T6, T7, T8) bacteria concentration

$\mathrm{T} 8 \mathrm{vs}$. T10. Influence of including a second bacteria inoculation (T10)

FigURE 6. Average compressive strength (points) and dispersion of this variable (arrows) obtained by the uniaxial unconfined compressive tests carried out on specimens subjected to different MICP treatments (T1-T10 according with Table 2) for (a) small particle sand soil, (b) coarse sand soils, (c) clayey sand soil and (d) sandy clay soil.

In contrast, clayey soils reached greater compressive strength ( $19 \%$ for M2, no significant change for M1, which was compacted with insufficient moisture content after treatment, see Table 5) when compacted after urea and calcium chloride treatment irrigation. The expected size of the voids is consistent with these results. The compaction process closed the larger voids in sandy soils, reducing bacterial removal due to irrigation flow. Thus, compacting before irrigation resulted in higher compressive strength for SS and CS soils because more bacteria remained in the soil to accelerate MICP. In contrast, clayey soils had few and poorly interconnected voids. The plugging effect reported in (14) was the main issue for these soils, rather than bacterial removal. Plugging the top surface voids prevented treatment irrigation from reaching all samples' depth, resulting in a heterogeneous specimen whose compressive strength was limited by the weaker lower part of the specimen. This was confirmed by the failure mode observed in the unconfined compressive strength tests. Greater compressive strength was reached when clayey soil voids were kept open until the MICP process was completed. MICP generated small particles that filled the original voids when compacted after treatment. Thus, it is important to compact sandy soils before treatment irrigation and do the opposite for clayey soil to get the best performance of the combined compaction-MICP process.

\subsection{Replacing Bang medium with distilled water}

Replacing the Bang medium with distilled water decreased the compressive strength in almost all cases $(\mathrm{CBB}$ and $\mathrm{CAB}$ vs. $\mathrm{CBD}$ and $\mathrm{CAD}$ in Table 6) because the nutrients in the Bang medium 
Soil biostabilisation and interaction with compaction processes for earthen engineering structures production $\bullet 11$

TABLE 5. Moisture content at the compaction moment for specimens compacted after treatment and comparison with optimum values.

\begin{tabular}{cccccccccccccc}
\hline & \multicolumn{4}{c}{ Moisture content (\%) } & \multicolumn{4}{c}{ Optimum Moisture content (\%) } & \multicolumn{3}{c}{ Difference respect optimum (\%) } \\
\hline Experiment & SS & CS & M1 & M2 & SS & CS & M1 & M2 & SS & CS & M1 & M2 \\
\hline CAB & 9.47 & 5.83 & 11.84 & 15.23 & \multirow{2}{*}{9.26} & \multirow{2}{*}{5.67} & \multirow{2}{*}{15.66} & \multirow{2}{*}{16.42} & 2.3 & 2.8 & -24.4 & -7.2 \\
\hline CAD & 9.15 & 5.40 & 15.04 & 14.60 & & & & & -1.2 & -4.8 & -4.0 & -11.1 \\
\hline
\end{tabular}

TABLE 6. Average compressive strength.

\begin{tabular}{cccccc}
\hline \multirow{2}{*}{ Soil } & \multicolumn{5}{c}{ Compressive strength (kPa) } \\
\cline { 2 - 6 } & CBN & CBB & CBD & CAB & CAD \\
\hline SS & 47.1 & 62.4 & 37.5 & 55.1 & 31.0 \\
\hline CS & 74.3 & 38.6 & 39.5 & 20.6 & 16.4 \\
\hline M1 & 355.5 & 224.0 & 185.8 & 203.6 & 259.0 \\
\hline M2 & 858.7 & 791.6 & 503.0 & 940.4 & 729.9 \\
\hline
\end{tabular}

were required for bacterial deployment, and especially for bacterial growth. Two exceptions were found: CS soil compacted before treatment, which showed no clear influence (see CBB and CBD tests for CS soil in Table 6) and M1 soil compacted after treatment (see $\mathrm{CAB}$ and CAD tests for M1 soil in Table 6). This exception was due to the anomalous low compressive strength of M1_CAB specimens resulting from an insufficient moisture content at compaction ( $24.4 \%$ less than optimum, Table 5). Thus, the moisture content during the compaction process was more influential than the Bang vs. distilled water selection in the MICP process. This fact proves that a suitable compaction process brought greater mechanical strength results than MICP treatment.

\subsection{Load bearing capacity and compressive stiffness}

The stress-deflection plots of the load-bearing experiments are presented in Figure 7. The real moisture content at compaction for the M2 Biostabilised sample was $14.94 \%$ (optimum was $16.42 \%)$. The moisture content in the load-bearing experiment was not the same for all samples. The moisture content was $3.80 \%, 4.28 \%, 6.67 \%$, and $0.87 \%$ for SS_Control, SS Biostabilised, M2 Control, and $\overline{\mathrm{M}} 2$ Biostabilised, respectively. The ballast coefficient was obtained from the previous stress-deformation curves at different deflection ranges. The results are summarised in Table 7.

It was observed that the biostabilised soil specimens were initially stiffer (averaging a $45 \%$ increase) than the control specimens, but the mechanical response was the opposite for deflections over $5 \mathrm{~mm}$ (see the slope of the curves in Figure 7 and
TABLE 7. Ballast coefficient at different testing stages.

\begin{tabular}{cccccc}
\hline & \multicolumn{5}{c}{ Ballast coefficient $(\mathrm{kPa} / \mathrm{mm})$ depending on } \\
Soil & $\begin{array}{c}0-5 \\
\mathrm{~mm}\end{array}$ & $\begin{array}{c}5-10 \\
\mathrm{~mm}\end{array}$ & $\begin{array}{c}10-15 \\
\mathrm{~mm}\end{array}$ & $\begin{array}{c}15-20 \\
\mathrm{~mm}\end{array}$ & $\begin{array}{c}20-25 \\
\mathrm{~mm}\end{array}$ \\
\cline { 2 - 6 } & 73.1 & 101.8 & 57.5 & 24.7 & 4.9 \\
\hline SS & 110.8 & 72.3 & 28.7 & 14.7 & 4.8 \\
\hline $\begin{array}{c}\text { SS_Biosta- } \\
\text { bilised }\end{array}$ & 11.7 & --- & -- \\
\hline M2 & 99.5 & 54.1 & -- & -- \\
\hline $\begin{array}{c}\text { M2_Biosta- } \\
\text { bilised }\end{array}$ & 138.9 & 52.4 & 25.1 & 36.0 & -- \\
\hline
\end{tabular}

the data in Table 7), proving that the top surfaces of biostabilised specimens were stiffer than the rest of the soil. Irrigation treatments were applied to the top surfaces, which were also directly exposed to the air. It was concluded that the MICP process preferentially occurred at the surface of the specimens because of (i) the plugging effect, which blocked calcium ions from deep penetration into the specimen, especially in M2 soil, and (ii) greater oxygen availability in the top surface, which increased bacterial activity, especially in SS soil. Although oxygen is not strictly required, Sporosarcina pasteurii activity increases in aerobic environments (39)treatment uniformity, cost, environmental impact, site accessibility requirements, etc. All of these methods have benefits and drawbacks, and there continues to be a need to explore new possibilities of soil improvement, particularly as suitable land for development becomes more scarce. This paper presents the results of a study in which natural microbial biological processes were used to engineer a cemented soil matrix within initially loose, collapsible sand. Microbially induced calcite precipitation (MICP. This fact reported in literature was confirmed from a practical point of view.

The final compressive strength of the control and biostabilised specimens was the same because the MICP process was locally developed at the surface, which did not change the overall response of the tested blocks; this conclusion must be verified through future diffusion experiments. The compressive strength of the M2 control specimen was abnormally lower than that of the biostabilised specimen because of its higher moisture content at the time of testing $(6.67 \%$ 
for control M2 vs. $0.87 \%$ for biostabilised M2). Thus, the observed increase in the compressive strength of the biostabilised M2 specimen (Figure 5) was not realistic, and this data was discarded from the analysis.

From a practical point of view, load-bearing tests showed that MICP is not effective at enhancing mechanical properties of soils if only superficial treatment was used. Hence, studying the possibility of in-depth injections is required in future researches.

\subsection{Optimal solution per soil}

The best general stabilisation procedure was to supply the maximum concentration of Sporosarcina pasteurii (including a second inoculation $24 \mathrm{~h}$ after the first one) and the maximum concentration of calcium chloride, using the Bang medium for solving urea and calcium chloride during treatment irrigation. There were minor procedural differences depending on the soil to be stabilised: (i) CS did not benefit from a second bacterial inoculation because of its larger pore size; (ii) SS and M2 soils benefitted from greater irrigation frequency $(2 \mathrm{~h})$; (iii) sandy soils should be compacted before treatment and clayey soils after treatment. The optimal stabilisation procedure for each soil is summarised in Table 8.

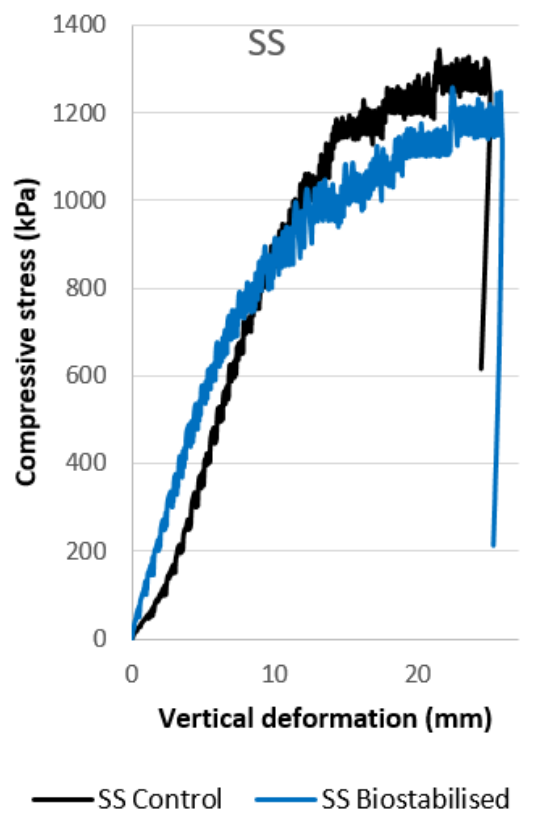

(a)
TABLE 8. Optimal stabilisation procedure. Maximum bacteria concentration, maximum calcium concentration and using Bang medium for treatment preparation was common criteria for all soils.

\begin{tabular}{cccc}
\hline Soil & $\begin{array}{l}\text { Second } \\
\text { inoculation }\end{array}$ & $\begin{array}{l}\text { Treatment } \\
\text { period (h) }\end{array}$ & $\begin{array}{l}\text { Compaction before/after } \\
\text { treatment }\end{array}$ \\
\hline SS & Yes & 2 & Before \\
\hline CS & No & 4 & Before \\
\hline M1 & Yes & 4 & After \\
\hline M2 & Yes & 2 & After \\
\hline
\end{tabular}

The experimental results (Table 6) demonstrated that Sporosarcina pasteurii MICP did not increase the compressive strength of compacted CS and M1 soils. CS soils were sensitive to bacterial removal during irrigation cycles. Hence, supplying all required resources at the initial soil mixing should be studied in future development of CS soil stabilisation, setting the research line for this specific type of soil. In contrast, the M1 soil particle size distribution was adequate for optimum compaction results. In this case, the benefits of MICP did not compensate for its potential issues: void formation at bacteria sporulation, fine particle removal during irrigation treatments, and breaking of clay bonds due to late calcium carbonate precipitation. In conclusion, MICP is beneficial for those cases which cannot be properly compacted because of a non-suitable par-

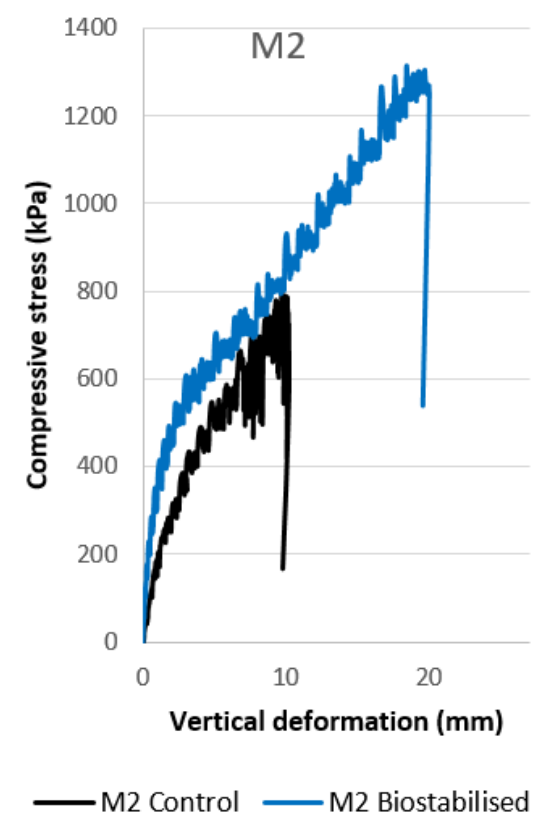

(b)

FIGURE 7. Stress-deformation results of the comparative load bearing experiments on control (black) and biostabilised (blue) specimens of (a) small particle sand soil and (b) sandy clay soil. 
ticle size distribution or excessive moisture content that cannot be fixed.

\subsection{Practical implications of the obtained results}

The compressive strength results are not complete enough to design stabilisation solutions for practical applications in a generic way; further research is necessary to determine the deformability in dryingwetting cycles, to analyse the water resistance and freeze-thaw resistance, and to study the cohesivefrictional response of biostabilised soils. Only a hypothesis on how these properties may be affected by the proposed MICP can be considered from the results of the current research. Considering that bacterial sporulation is likely to produce a significant void volume, it is expected that the structure may be more stable in drying-wetting cycle deformability and freezing/thawing conditions. The additional porosity may lead to minor water resistance. All these hypothesis are worth for future research.

Obtaining aggregated calcium carbonate requires high bacterial and calcium concentrations, which are not likely to be provided in field applications. Thus, soils biostabilised with the proposed methodology are not expected to exhibit increased cohesive behaviour, but rather a frictional response from the production of small disaggregated particles due to lower bacteria and calcium concentrations. As a practical conclusion, MICP in civil engineering and architectural applications has not to be aimed to increase the cohesion of the soils.

The time required for the complete biostabilisation process (up to three weeks in some cases) is similar to the full hydration time of cement. However, cement may be sufficiently effective in 2-4 days, whereas the minimum required MICP treatment time is 10-14 days, according to the current results. MICP is not time saving respect common binders stabilisation.

The average cost of the performed treatments is approximately 50 times higher than the cost of Portland cement alternatives. Thus, the technology is not economically competitive at the current state of development compared to other available alternatives, and may only be justifiable if common stabilisers are forbidden due to sustainability reasons.

\section{CONCLUSIONS}

The effectiveness of MICP as a soil stabilisation procedure and its interaction with compaction processes depend on the soil particle size distribution. The following conclusions are drawn from the experimental evidence:

- Kinetics experiments in aqueous media proved that a higher concentration of Sporosarcina pas- teurii cells produces a larger number of calcium carbonate particles and a smaller particle size. This allows deeper penetration of MICP treatments. Higher concentrations of calcium chloride produce greater aggregation of precipitated calcium carbonate particles.

- Treatment tests showed that calcium carbonate precipitates from calcium chloride and urea presence, whereas Sporosarcina pasteurii acts as a catalyser of this reaction. It was also proved that periodic irrigation contributes to bacterial removal. This effect was more evident in interconnected porous soils. However, periodic repetition of the treatment makes it possible to enhance calcium carbonate precipitation after the first bacterial removal except for the coarsest soils. In addition, increasing bacterial concentration also increased calcium carbonate precipitation for all soils. Finally, calcium carbonate precipitation has counterproductive effects in clayey soils when it interacts with drying process.

- It is better to compact sandy soils before MICP treatment irrigation because compaction limits the possibility of sweeping out bacteria with the irrigation flow. In contrast, it is better to compact clayey soils after MICP treatment irrigation to avoid the superficial plugging effect. Greater oxygen availability on the irrigated surfaces concentrate the MICP effect in the top layer. The compressive strength of soils characterised by small sand particles (SS) or a large amount of clay (M2) can be locally improved by MICP (32\% and $10 \%$ respectively), compared with compaction alone.

- Coarse sand soils (CS) cannot be effectively biostabilised because of their larger interconnected voids and soils with an optimum particle size distribution (M1) reached their greatest strength by compaction alone. The limited positive effect of biostabilisation does not compensate for the associated void generation at bacteria sporulation or fine particle sweeping due to irrigation in the case of soils with an optimum particle size distribution (M1).

From a practical point of view, it is concluded that MICP treatment combined with compaction procedure contribute to increase the compressive strength for those soils whose particle size distribution has more than half of the particles in the range between $0.125 \mathrm{~mm}$ and $0.5 \mathrm{~mm}$. Regarding soil composition, MICP-compaction combined procedure shows better performance on those soils with lowest clay content.

Combined MICP-compaction procedure is effective for small particles sandy soils with no clay content. However, the qualitatively observed low performance-cost ratio of this process makes it suitable for cases in which other binding agents are banned only. 


\section{ACKNOWLEDGMENTS}

Corresponding author is a Serra Húnter Fellow. Authors also acknowledge the support provided by Joan Sánchez and Abdul Rahman Bin Umar at developing experimental tests.

\section{AUTHOR CONTRIBUTIONS:}

Conceptualization: E. Bernat-Maso, M.J. Lis, E. Teneva. Data curation: E. Bernat-Maso, E. Teneva. Formal analysis: E. Bernat-Maso, L. Gil, M.J. Lis. Funding acquisition: L. Gil. Investigation: E. Bernat-Maso, M.J. Lis, E. Teneva. Methodology: E. Bernat-Maso, L. Gil, M.J. Lis. Project administration: L. Gil. Resources: L. Gil. Supervision: E. Bernat-Maso, L. Gil. Visualization: L. Gil. Roles/Writing, original draft: E. Bernat-Maso, E. Teneva. Writing, review \& editing: E. Bernat-Maso, L. Gil, M.J. Lis.

\section{REFERENCES}

1. Easton, D.; Wright, C. (2007) The rammed earth house, Chelsea Green Publishing, Vermont (2007).

2. Minke, G. (2012) Building with earth. Design and technology of a sustainable architecture, Third Edit, Birkhäuser Berlin, Boston (2012). https://doi.org/10.1515/9783034608725.

3. Chang, I.; Jeon, M.; Cho, G.C. (2015) Application of microbial biopolymers as an alternative construction binder for earth buildings in underdeveloped countries. Int. J. Polym. Sci. 1-9. https://doi.org/10.1155/2015/326745.

4. Achal, V.; Mukherjee, A. (2015) A review of microbial precipitation for sustainable construction. Constr. Build. Mater. 93, 1224-1235. https://doi.org/10.1016/j. conbuildmat.2015.04.051.

5. Omoregie, A.I.; Khoshdelnezamiha, G.; Ong, D.E.L.; Nissom, P.M. (2017) Microbial-induced carbonate precipitation using a sustainable treatment technique. Int. J. Serv. Manag. Sustain. 2 [1], 17-31. Retrieved from http://www.ijsmssarawak.com/ ijsms_vol_2/No2_MICP_Armstrong.pdf.

6. Cheng, L.; Shahin, M.A. (2019) Microbially induced calcite precipitation (MICP) for soil stabilization. Ecological wisdom inspired restoration engineering. 47-68. https://doi. org/10.1007/978-981-13-0149-0_3.

7. Mujah, D.; Shahin, M.A.; Cheng, L. (2017) State-of-the-art review of biocementation by microbially induced calcite precipitation (MICP) for soil stabilization. Geomicrobiol. $J$. 34 [6], 524-537. https://doi.org/10.1080/01490451.2016.122 5866 .

8. Ivanov, V.; Chu, J; (2008) Applications of microorganisms to geotechnical engineering for bioclogging and biocementation of soil in situ. Rev. Environ. Sci. Bio/Technology. 7, 139-153. https://doi.org/10.1007/s11157-007-9126-3.

9. Whiffin, V.S.; Van Paassen, L.A.; Harkes, M.P. (2007) Microbial carbonate precipitation as a soil improvement technique. Geomicrobiol. J. 24 [5], 417-423. https://doi. org/10.1080/01490450701436505.

10. Dhami, N.K.; Reddy, M.S.; Mukherjee, A. (2013) Biomineralization of calcium carbonates and their engineered applications: a review. Front. Microbiol. 4, 1-13. https://doi. org/10.3389/fmicb.2013.00314.

11. Wei, S.; Cui, H.; Jiang, Z.; Liu, H.; He, H.; Fang, N. (2015) Biomineralization processes of calcite induced by bacteria isolated from marine sediments. Brazilian J. Microbiol. 46 [2], 455-464. https://doi.org/10.1590/S1517-838246220140533.

12. Al-Thawadi, S. (2011) Ureolytic bacteria and calcium carbonate formation as a mechanism of strength enhancement of sand. J. Adv. Sci. Eng. Res. 1, 98-114. Retrieved from https://www.researchgate.net/publication/230603500 Ureolytic Bacteria and Calcium Carbonate Formation as_a_Mechanism_of_Strength_Enhancement_of__Sand.

13. Ginn, T.R.; Murphy, E.M.; Chilakapati, A.; Seeboonruang, U. (2001) Stochastic-convective transport with nonlinear reaction and mixing: application to intermediate-scale experiments in aerobic biodegradation in saturated porous media. J. Contam. Hydrol. 48 [1-2], 121-149. https://doi. org/10.1016/S0169-7722(00)00168-6.

14. Cheng, L.; Cord-Ruwisch, R. (2014) Upscaling effects of soil improvement by microbially induced calcite precipitation by surface percolation. Geomicrobiol. J. 31 [5], 396-406. https://doi.org/10.1080/01490451.2013.836579.

15. Ivanov, V.; Chu, J.; Stabnikov, V. (2015) Basics of construction microbial biotechnology. Biotechnologies and biomimetics for civil engineering, Springer International Publishing. 21-56 (2015). https://doi.org/10.1007/978-3319-09287-4 2.

16. Ferris, F.G.; Stehmeier, L.G. (1992) Bacteriogenic mineral plugging. United States patent. Retrieved from https:// patents.google.com/patent/US5143155A/id.

17. Springham, D.G. (1984) Microbiological methods for the enhancement of oil recovery. Biotechnol. Genet. Eng. Rev. 1 [1], 187-222. https://doi.org/10.1080/02648725.1984.10647786.

18. Finnerty, W.R.; Singer, M.E. (1983) Microbial enhancement of oil recovery. Nat. Biotechnol. 1, 47-54. https://doi. org/10.1038/nbt0383-47.

19. Jonkers, H.M.; Thijssen, A.; Muyzer, G.; Copuroglu, O.; Schlangen, E. (2010) Application of bacteria as selfhealing agent for the development of sustainable concrete. Ecol. Eng. 36 [2], 230-235. https://doi.org/10.1016/j. ecoleng.2008.12.036.

20. Van Tittelboom, K.; De Belie, N.; De Muynck, W.; Verstraete, W. (2010) Use of bacteria to repair cracks in concrete. Cem. Concr. Res. 40 [1], 157-166. https://doi.org/10.1016/j. cemconres.2009.08.025.

21. Bang, S.S.; Lippert, J.J.; Yerra, U.; Mulukutla, S.; Ramakrishnan, V. (2010) Microbial calcite, a bio-based smart nanomaterial in concrete remediation.Int.J. Smart Nano Mater 1 [1], 28-39. https://doi.org/10.1080/19475411003593451.

22. Jonkers, H.M. (2011) Bacteria-based self-healing concrete. Heron. 56 [1-2], 5-16.

23. Wang, J.Y.; Soens, H.; Verstraete, W.; De Belie, N. (2014) Self-healing concrete by use of microencapsulated bacterial spores. Cem. Concr. Res. 56, 139-152. https://doi. org/10.1016/j.cemconres.2013.11.009.

24. Sierra-Beltran, M.G.; Jonkers, H.M.; Schlangen, E. (2014) Characterization of sustainable bio-based mortar for concrete repair. Constr. Build. Mater. 67, 344-352. https://doi. org/10.1016/j.conbuildmat.2014.01.012.

25. Vijay, K.; Murmu, M.; Deo, S.V. (2017) Bacteria based self healing concrete - A review. Constr. Build. Mater. 152, 1008 1014. https://doi.org/10.1016/j.conbuildmat.2017.07.040.

26. Ivanov, V.; Stabnikov, V. (2017) Construction biotechnology. Biogeochemistry, microbiology and biotechnology of construction materials and processes, Springer, Ed. Singapore (2017). https://doi.org/10.1007/978-981-10-1445-1.

27. Della Vecchia, G.; Morales, L.; Garzón, E.; Jommi, C.; Romero, E. (2010) Modelling criteria for a microbiologically stabilised compacted soil in the framework of elastoplasticity. Unsaturated Soils, Two Volume Set (1st ed.). In E. Alonso \& A. Gens (Eds.), 5th International Conference on Unsaturated Soils. Barcelona: Taylor\&Francis. 795-801.

28. Arya, C.F.; Augustine, J.; Parengal, H.; Ravindran, A.D. (2016) Microbial geotechnology: evaluation of strength and structural properties of microbial stabilized mud block (MSMB). Int. J. Sci. Eng. Res. 7 [1], 278-282. Retrieved from https://www.ijser.org/researchpaper/MICROBIALGEOTECHNOLOGY-EVALUATION-OF-STRENGTHAND-STRUCTURAL-PROPERTIES-OF-MICROBIALSTABILIZED-MUD-BLOCK-MSMB.pdf.

29. Mutitu, K.D.; Munyao, M.O.; Wachira, M.J.; Mwirichia, R.; Thiong'o, K.J.; Marangu, M.J. (2019) Effects of biocementation on some properties of cement-based materials incorporating Bacillus Species bacteria - a review. J. Sustain. Cem. Mater. 8 [5], 309-325. https://doi.org/10.1080/216503 73.2019.1640141.

30. Morales, L.; Romero, E.; Jommi, C.; Garzón, E.; Giménez, A. (2014) Feasibility of a soft biological improvement of natural soils used in compacted linear earth construction. Acta Geotech. 10, 157-171. https://doi.org/10.1007/s11440014-0344-x. 
31. De Muynck, W.; Debrouwer, D.; De Belie, N.; Verstraete, W. (2008) Bacterial carbonate precipitation improves the durability of cementitious materials. Cem. Concr. Res. 38 [7], 1005-1014. https://doi.org/10.1016/j. cemconres.2008.03.005.

32. Van Paassen, L.A.; Harkes, M.P.; Van Zwieten, G.A.; Van Der Zon, W.H.; Van Der Star, W.R.L.; Van Loosdrecht, M.C.M. (2009) Scale up of biogrout: a biological ground reinforcement method. Proc. 17th Int. Conf. Soil Mech. Geotech. Eng. Acad. Pract. Geotech. Eng. 3, 2328-2333. https://doi.org/10.3233/978-1-60750-031-5-2328.

33. Bang, S.S.; Galinat, J.K.; Ramakrishnan, V. (2001) Calcite precipitation induced by polyurethane-immobilized bacillus pasteurii. Enzyme Microb. Technol. 28 [4-5], 404-409. https://doi.org/10.1016/S0141-0229(00)00348-3.

34. ASTM C42 / C42M-20, Standard test method for obtaining and testing drilled cores and sawed beams of concrete, ASTM International, West Conshohocken, PA. 2020. https://doi. org/10.1520/C0042 C0042M-20.

35. Bernat-Maso, E.; Gill, L.; Escrig, C.; Barbé, J.; Cortés, P. (2018) Effect of Sporosarcina Pasteurii on the strength properties of compressed earth specimens. Mater. Constr. 68
[329], e143. https://doi.org/10.3989/mc.2018.12316.

36. ASTM D1557-12e1, Standard test methods for laboratory compaction characteristics of soil using modified effort $\left(56,000 \mathrm{ft}-\mathrm{lbf} / \mathrm{ft}^{3}\left(2,700 \mathrm{kN}-\mathrm{m} / \mathrm{m}^{3}\right)\right)$, ASTM International, West Conshohocken, PA. 2012. https://doi.org/10.1520/ D1557-12E01.

37. Bernat-Maso, E.; Teneva, E.; Escrig, C.; Gil, L. (2017) Ultrasound transmission method to assess raw earthen materials. Constr. Build. Mater. 156, 555-564. https://doi. org/10.1016/j.conbuildmat.2017.09.012.

38. ASTM D1194-94, Standard test method for bearing capacity of soil for static load and spread footings (Withdrawn 2003), ASTM International, West Conshohocken, PA. 1994. https:// doi.org/10.1520/D1194-94.

39. DeJong, J.T.; Fritzges, M.B.; Nüsslein, K. (2006) Microbially induced cementation to control sand response to undrained shear. J. Geotech. Geoenvironmental Eng. 132 [11], 1381-1392. https://doi.org/10.1061/(ASCE)10900241(2006)132:11(1381).

40. Kubantseva, N.; Hartel, R.W. (2002) Solubility of calcium lactate in aqueous solution. Food Rev. Int. 18 [2-3], 135-149. https://doi.org/10.1081/FRI-120014355. 